\title{
Balanophoraceae, SE Asia: On the identity of Balanophora involucrata Hook.f. and B. flava (Hook.f.) Lidén comb. nov.
}

\author{
Magnus Lidén \\ Systematic Biology, Uppsala University, Norbyvägen 18D, 75236 Uppsala, Sweden. \\ E-mail:magnus.liden@ebc.uu.se.
}

[Received 20.02.2019; Revised 07.05.2019; Accepted 08.05.2019; Published 30.06.2019]

\begin{abstract}
Correct names are established for two species confused under the name Balanophora involucrata Hook.f. A new combination B. flava (Hook.f.) Lidén is necessitated.
\end{abstract}

Key words: Balanophora involucrata, Balanophora flava, SE Asia, Nomenclature

Balanophora sect. Dibivolva (Tiegh.) B.Hansen, distributed in the Himalayas and into Indochina and China, is technically defined by three tepals and a collar ("involucrum") of fused scale-leaves on flowering stems. The section thus circumscribed includes a dioecious and a monoecious taxon. Hooker (1856), in a study of Indian species of Balanophora, treated them as a single species, $B$. involucrata Hook.f., and recognized the taxa at varietal level. In his global monograph, Hansen (1972), having seen only museum specimens, likewise treated them as conspecific, but without formal subdivision. van Tiegheim (1907) and Huang \& Murata (2003), on the other hand, recognized two species, as there are striking characters correlated with the monoecy/dioecy distinction, and no intermediates are known, same for colour of stems and number of male flowers which, according to Hooker, can vary within populations.

Male plants of the dioecious species have bracts fused into a bee cake pattern of alveoli from which emerge long-stalked flowers with yellow to whitish perianth (Figure 1), whereas the monoecious species has free bracts and short-stalked male flowers with red perianth (Figure 2). A similar distinction is found between the female flowers (Figures 1,2). Possibly there are also differences in host plant preferences. Both, Hooker and Hansen recorded several woody species, but without discriminating between the two forms.

With these substantial differences, and lack of intermediates, I see no reason at all to question the recent taxonomic conclusions by Huang \& Murata. Unfortunately, however, they erroneously applied the epithet involucrata to the dioecious taxon while using fargesii for the monoecious one.

Hooker (1856 pl. IV, V, VI) illustrated the monoecious taxon as B. involucrata without varietal designation (although it was given as ? rubra in the text). The dioecious taxon was recognized as var. flava and var. cathcartii. Subsequently, van Tiegheim (1907) elevated flava and cathcartii to specific rank under Bivolva, keeping involucrata for the monoecious taxon. Finally, Hansen (1972) selected a monoecious Hooker specimen in K as lectotype for the name Balanophora involucrata.

A new species level combination is thus needed under Balanophora for the dioecious taxon, for which flava and cathcartii, being simultaneously published (1856 at varietal rank, 


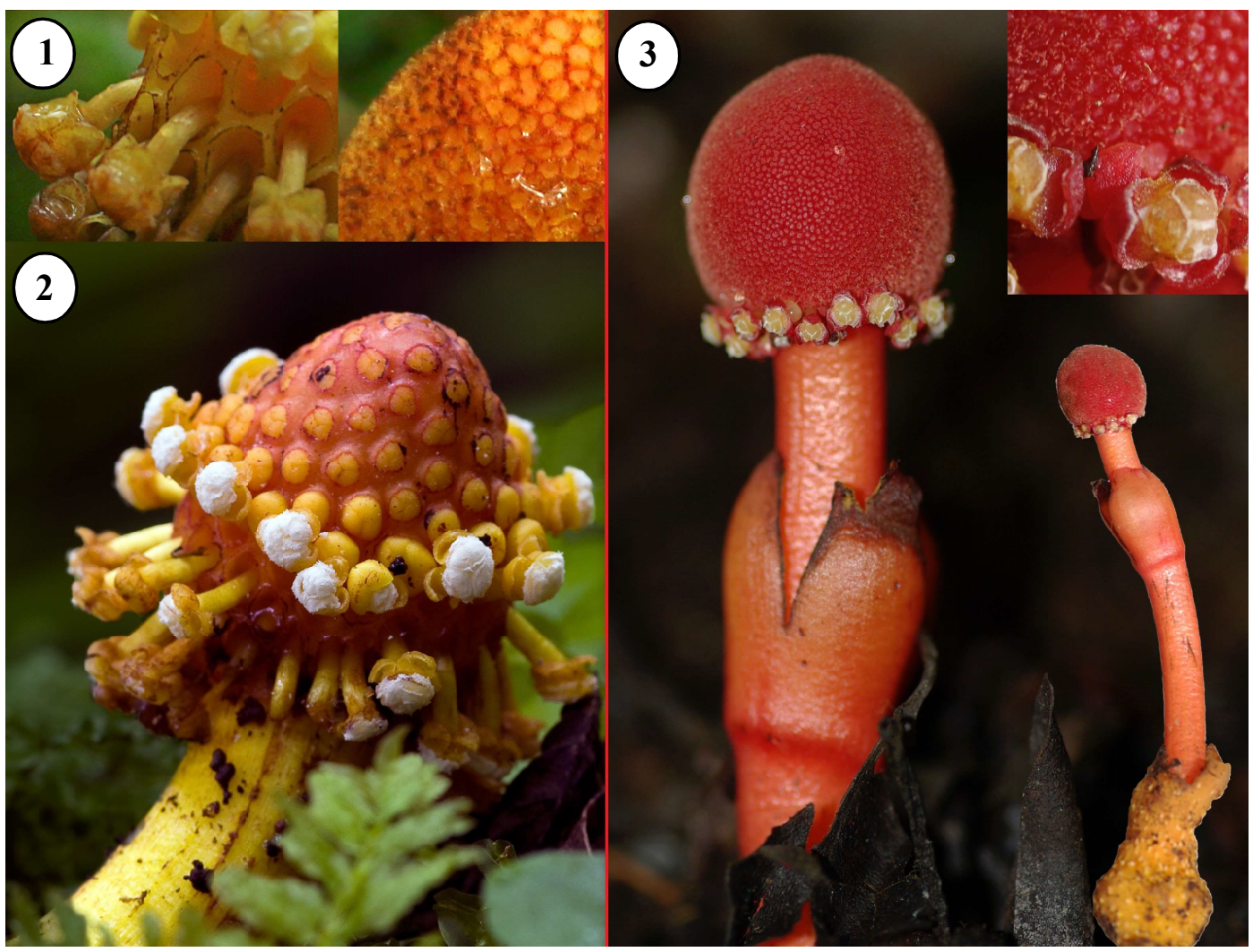

PLATE - I. Left: Balanophora flava. Male (bottom and upper left): India, Arunachal Pradesh, Anjaw: E of Dong, 2500-3000 m, under Rhododendron, common. (photo: ML 3/8 2010). Female (upper right): Sikkim, near Lachung, (photo: Love Lidén 20.07. 2016). - Right: Balanophora involucrata. China, Yunnan: S of Lake Lugo, 3200 m, mixed forest. (photo: ML 11.08. 2007).

1907 at species rank), are competing epithets. As flava is represented by herbarium specimens (incl. a lectotype), cathcartii only by pickled material, flava is my preferred choice.

1. Balanophora flava (Hook.f.) Lidén, comb. nov.: B. involucrata var. flava Hook.f., Trans. Linn. Soc. Lond. 22(1): 44. 1856. Bivolva flava (Hook.f.) Tiegh., Ann. Sci. Nat., Bot. sér. 9, 6: 205. 1907 - Type: India, Sikkim, 8-12000' [Lachen, Aug 4], J. D. Hooker s.n., (as "Balanophora flava", K000674594, lectotype selected by Hansen 1972).

= B. involucrata var. cathcartii Hook.f., Trans. Linn. Soc. London 22(1): 44. 1856. Bivolva cathcartii (Hook.f.) Tiegh, Ann. Sci. Nat., Bot. sér. 9, 6: 205. 1907. Balania cathcartii (Hook.f.) Setch., Hong Kong Naturalist Suppl. 1: 11. 1932 - Type: Hooker, Sikkim, $9000 \mathrm{ft}$ [2743 m], specimen in spirit (K), see tab.VII in Hooker (1856). At http://specimens.kew.org/ herbarium/29047.206 and 37577.000) erroneously recorded as var cathartica.

$=\alpha$ B. involucrata var. gracilis Hook.f., Trans. Linn. Soc. London 22(1): 44.1856 see tab. VII in Hooker (1856), no specimen.

Balanophora harlandii Hook.f. is another dioecious species with long-stalked male flowers emerging from hexagonal pits of a bee-cake structure of fused bracts (this is also 
emphasised by Huang \& Murata), but it is distinguished from B. flava by spiral or at most sub-opposite leaves, colour, host and altitude preferences. Their close morphological similarity nevertheless brings into question the circumscription of sect. Dibivolva, which is based only on the presence of an "involucrum", as it seems highly probable that $B$. flava is more closely related to $B$. harlandii than to $B$. involucrata.

2. Balanophora involucrata Hook.f., Trans. Linn. Soc. London, Bot. 22 (1): 30. 1856. Bivolva involucrata (Hook.f.) Tiegh., Ann. Sci. Nat., Bot. sér. 9, 6: 205. 1907. Type: India, Sikkim, $7000-9000 \mathrm{ft}[2133-2743$ m], J. D. Hooker s.n. (K000674596, lectotype selected by Hansen 1972).

= Bivolva fargesii Tiegh., Ann. Sci. Nat., Bot. sér. 9, 6: 206. 1907. Balanophora fargesii (Tiegh.) Harms in Engler \& Prantl, Nat. Pflanzenfam., ed. 2. 16b. 332. 1935. Type: China, E Sichuan, Tchen-keou-tin, P. Farges s.n. (P, lectotype selected by Hansen 1972; iso, K).

\section{LITERATURE CITED}

Hansen, B. 1972. The genus Balanophora J. R. \& G. Forster, a taxonomic monograph. Dansk Botanisk Arkiv 28(1): 188. Köpenhamn.

Hooker, J. D. 1856. On the structure and affinities of Balanophoreae. Trans. Linn. Soc. Lond. 22(1): 44.

Huang S-M \& J. Murata. 2003. Balanophoraceae, pp. 272 - 276. In Wu Z-Y \& P. H. Raven (eds), Flora of China vol. 5 (www).

Tiegheim, P. van. 1907. Sur les Inovulées. Ann. Sci. Nat., Bot. sér. 9, 6: 125 - 260. 